\title{
ISLAM DAN PENGUATAN CIVIL SOCIETY DI INDONESIA
}

\author{
Besse Tenriabeng Mursyid ${ }^{1}$ \\ Fakultas Syariah IAIN Palu \\ e-mail: bmursyid@iainpalu.ac.id
}

\begin{abstract}
The idea and strengthening of civil society praxis is an alternative model for the struggle towards democratization. In Indonesia, efforts to strengthen civil society cannot be separated from Islam as the religion practiced by the majority of the Indonesian population. Efforts to strengthen civil society cannot ignore religious factors, especially Islam. In fact, in certain cases the existence of Muslims who are inspired by Islamic teachings is the basis for socio-cultural and even political change in Indonesia. The potential of Islamic teachings, which contain elements of beliefs and norms and ethical teachings related to the socio-cultural community practiced by Indonesian Muslims, are very large in determining the socio-cultural format of society. Likewise, in the effort to strengthen civil society, Muslims occupy a leading position which can be expected to be a counterweight to the country's dominant tendency. In other words, quantitatively, Muslims based on Islamic teachings have a prerequisite for the growth and strengthening of civil society in Indonesia. Islam as a religion that is embraced by the majority of Indonesians is a solid foundation in encouraging the strengthening of civil society in Indonesia.
\end{abstract}

Keywords: Islam, Strengthening, Civil Society

\begin{abstract}
Abstrak
Gagasan dan penguatan praksis civil society merupakan salah satu alternatif model perjuangan menuju demokratisasi. Di Indonesia berkaitan dengan upaya penguatan civil society tidak bisa dipisahkan dengan agama Islam sebagai agama yang dianut oleh mayoritas penduduk Indonesia. Upaya penguatan civil society tidak bisa mengabaikan faktor agama khususnya Islam. Bahkan dalam beberapa hal tertentu keberadaan umat Islam yang notabenenya diinspirasi oleh ajaran Islam merupakan basis perubahan sosio-kultural bahkan politik di Indonesia. Potensi ajaran Islam yang di dalamnya mengandung unsur keyakinan dan norma serta terdapat ajaran-ajaran etis yang berkaitan dengan sosio-kultural masyarakat yang dipraktekkan oleh muslim Indonesia sangat besar dalam menetukan format sosial-kultural masyarakat. Begitu pula dalam upaya penguatan civil society, muslim menduduki posisi terdepan yang bisa diharapkan bisa menjadi pengimbang dari kekuatan negara yang cenderung dominatif. Dengan kata lain secara kuantitatif umat Islam dengan berpijak pada
\end{abstract}

\footnotetext{
${ }^{1}$ Penulis merupakan Dosen tetap pada Fakultas Syariah IAIN Palu
} 
ajaran Islam memiliki prasyarat bagi pertumbuhan dan penguatan civil society di Indonesia. Islam sebagai sebuah agama yang dianut oleh mayoritas masyarakat Indonesia menjadi pondasi yang kokoh dalam mendorong penguatan civil society di Indonesia.

Kata Kunci: Islam, Penguatan, Civil Society

\section{A. Pendahuluan}

Term civil society atau masyarkat sipil merupakan wacana baru yang berkembang pada era tahun 1980an, yang awalnya diinspirasi oleh perkembangan yang terjadi pada negara-negara di benua Eropa ketika itu mereka sedang menjalani proses transformasi dari era politik rezim otoritarian komunis menuju era demokrasi. Yang kemudian dampaknya menyebar luas ke benua lain, meliputi Amerika Latin, Afrika dan Asia yang sedang menjalani masa transisi ke arah demokrasi. Wacana tentang masyarakat sipil mulai berkembang di Indonesia dan sering diperbincangkan pada dasarwarsa 1990-an sejak menguatnya tuntutan tentang reformasi dan demokratisasi terhadap rezim politik orde baru. Dan semenjak saat itu wacana masyarakat sipil mewarnai sistem perpolitikan Indonesia, yang umumnya dikaitkan dengan kelompok-kelompok masyarakat yang bersifat mandiri dan mengambil jarak bahkan vis a vis dengan struktur formal Negara.$^{2}$

Civil society sebagai sebuah gagasan merupakan produk pengalaman sejarah yaitu sejarah masyarakat Barat. Yang dalam perjalannya mengalami berbagai pemaknaan sesuai dengan konteks kesejarahan dan dinamika pemikiran tempat diterapkannya konsep tersebut. Di Indonesia devinisi terkait civil society diterjemahkan dengan berbagai pengertian tergantung devinisi yang dikemukakan oleh para tokoh yang mengakaji secara spesifik terkait persoalan tersebut.

Di Indonesia term civil society mengalami penerjemahan yang berbeda-beda pula seperti masyarakat sipil, masyarakat kewargaan atau masyarakat madani. Konsep "Masyarakat Madani” yang merupakan penerjemahan dari istilah civil society

\footnotetext{
${ }^{2}$ Adi Suryadi Culla, "Rekonstruksi Civil Society: Wacana dan Aksi Ornop di Indonesia" (Jakarta: Pustaka LP3ES Indonesia, 2006), hlm. 2
}

Qaumiyyah: Jurnal Hukum Tata Negara 
pertama kali disampaikan oleh Dato Seri Anwar Ibrahim dalam Simposium Nasional dalam rangka Forum Ilmiah pada acara Festifal Istiklal 26 September 1995 di Jakarta. Konsep ini hendak menunjukkan bahwa masyarakat ideal adalah kelompok masyarakat yang memiliki peradaban maju. Terjemahan civil society menjadi masyarakat madani ini, banyak diikuti oleh para cendekiawan dan ilmuwan di Indonesia seperti Nurcholish Madjid, Dawam Rahardjo, Azyumardi Azra, Abdurrahman Wahid dan sebagainya. ${ }^{3}$

Civil society atau masyarakat madani sebagaimana dikonsepsikan para pelopornya memiliki tiga ciri utama. Pertama, adanya kemandirian yang cukup tinggi dari individu-individu dan kelompok-kelompok dalam masyarakat, utamanya ketika berhadapan dengan Negara. Kedua, adanya ruang publik bebas (the free public sphere) sebagai wahana dari keterlibatan politik secara aktif warga negara melalui wacana dan praksis yang berkaitan dengan kepentingan publik. Ketiga, adanya kemampuan membatasi negara agar ia tidak intervensionis. ${ }^{4}$

Gagasan dan penguatan praksis civil society merupakan salah satu alternatif model perjuangan menuju demokratisasi. Di Indonesia berkaitan dengan upaya penguatan civil society tidak bisa dipisahkan dengan agama Islam sebagai agama yang dianut oleh mayoritas penduduk Indonesia. Upaya penguatan civil society tidak bisa mengabaikan faktor agama khususnya Islam. Bahkan dalam beberapa hal tertentu keberadaan umat Islam yang notabenenya diinspirasi oleh ajaran Islam merupakan basis perubahan sosio-kultural bahkan politik di Indonesia. Potensi ajaran Islam yang di dalamnya mengandung unsur keyakinan dan norma serta terdapat ajaran-ajaran etis yang berkaitan dengan sosio-kultural masyarakat yang dipraktekkan oleh muslim Indonesia sangat besar dalam menetukan format sosial-kultural masyarakat. Begitu pula dalam upaya penguatan civil society, muslim menduduki posisi terdepan yang bisa diharapkan bisa menjadi pengimbang dari kekuatan negara

${ }^{3}$ A. Ubaidillah...(et.al), "Pendidikan Kewargaan Demokrasi, HAM dan Masyarakat Madani" (cet.1) (Jakarta: IAIN Jakarta Press, 2000) hlm. 140

${ }^{4}$ Sufyanto, Masyarakat Tamaddun Kritik Hermeneutis Masyarakat Madani Nurcholish Madjid, (Yogyakarta: Pustaka Pelajar dan LP2IF, 2001) hlm. 113-115

Qaumiyyah: Jurnal Hukum Tata Negara 
yang cenderung dominatif. Dengan kata lain secara kuantitatif umat Islam dengan berpijak pada ajaran Islam memiliki prasyarat bagi pertumbuhan dan penguatan civil society di Indonesia. ${ }^{5}$

Tulisan ini akan memaparkan Islam dan penguatan civil society di Indonesia. Bagaimana Islam sebagai ajaran yang didalamnya mengandung unsur keyakinan dan norma serta terkandung ajaran-ajaran etik yang diterapkan dalam sistem sosiokultural masyarakat yang dapat menjadi inspirasi dan pendorong untuk penguatan civil society di Indonesia.

\section{B. Kerangka Teori}

Untuk menjelaskan dan menganalisis makalah dengan tema "Islam dan penguatan civil society di Indonesia" penulis menggunakan teori domestikasi Islam Harry J Benda sebagaimana yang termuat dalam kerangka teori sebagai berikut:

\section{TEORI DOMESTIKASI ISLAM HARRY J BENDA}

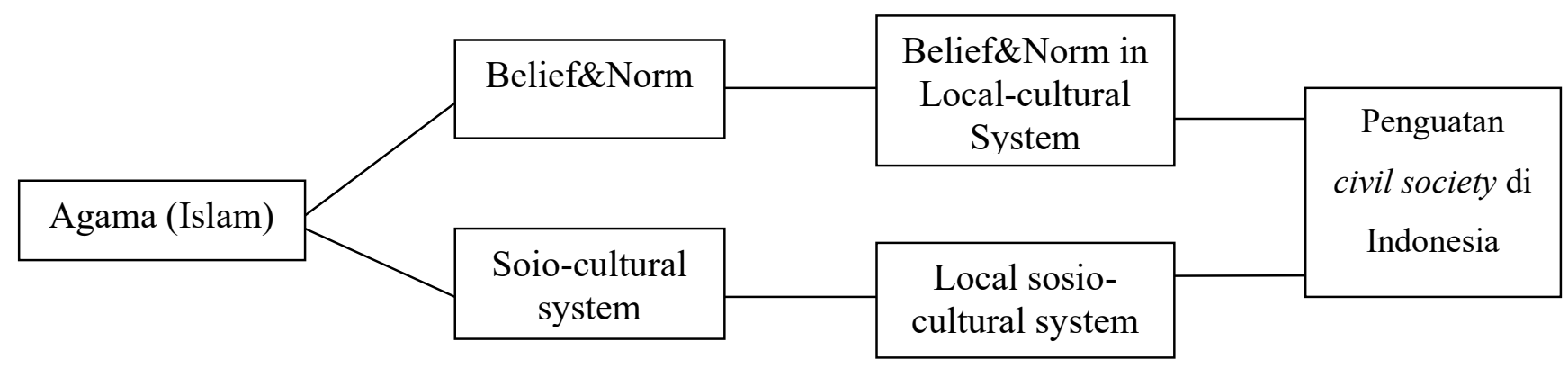

Mari kita lihat logika berfikir dalam kerangka teori domestikasi Islam Harry J. Benda ini di mana agama dalam hal ini adalah Islam di dalamnya terkandung berbagai ajaran baik yang menyangkut belief atau keyakinan dan juga norma-norma atau aturan-aturan, maupun yang berkaitan dengan sosial-budaya masyarakat. Ajaran ini terdomestikasi dan melakukan sinkretisasi atau perpaduan dengan budaya lokal

${ }^{5}$ Hendro Prasetyo...(et.al), "Islam dan Civil Society: Pandangan Muslim Indonesia" (Jakarta: PT Gramedia Pustaka Utama, 2002) hlm. 11

Qaumiyyah: Jurnal Hukum Tata Negara 
masyarakat, sehingga ajaran Islam ini menghasilkan dapat diterima oleh masyarakat dan menjadi pendorong terhadap penguatan civil society di Indonesia.

\section{Pembahasan}

Dalam pembahasan makalah ini terdiri dari tiga sub pokok bahasan: pertama, menjelaskan tentang konsep serta cakupan yang berkaitan dengan Islam dan civil society. Kedua, menjelasakan dan menguraikan sinkretisasi ajaran Islam dengan budaya lokal dalam konteks Indonesia. Dan ketiga menjelaskan bagaimana peran Islam dalam penguatan civil society di Indonesia.

\section{a. Islam dan Civil Society}

Berbicara tentang Islam dan civil society menjadi hal yang menarik, karena sejauh yang kita ketahui berdasarkan penelusuran sejarah dua konsep ini memiliki latar belakang yang berbeda dari segi kemunculan, cakupan maupun dari segi pemaknaan dan penerapan konsep ini. Akan tetapi, kedua konsep ini, bukan tidak mempunyai keterkaitan sama sekali. Dalam beberapa literatur yang ditulis oleh pemikir-pemikir Islam Indonesia seperti Abdurrahman Wahid, Nurcholish Madjid, Azyumardi Azra, Dawam Raharjo, dan sebagainya kadangkala menyamakan konsep civil society dengan istilah masyarakat madani yang diinspirasi dari praktek Nabi Muhammad dalam mengimplementasikan ajaran Islam di Madinah.

Sebelum menjelaskan konsep civil society lebih jauh, terlebih dahulu penulis akan menjelaskan terkait dengan persoalan Islam dari perspektif yang penulis pahami berdasarkan beberapa literatur hasil bacaan dan berdasarkan kerangka teori sebelumnya.

Endang Saifuddin Anshari mengemukakan dan menyimpulakan pengertian Islam sebagai berikut: ${ }^{6}$

1. Wahyu yang diurunkan oleh Allah SWT kepada Rasul-Nya untuk disampaikan kepada segenap umat manusia sepanjang masa dan meliputi Seluruh alam semesta.

${ }^{6}$ Endang Saifuddin Anshari, Kuliah Al-Islam, (Bandung: Pustaka 1978) hlm. 46 Qaumiyyah: Jurnal Hukum Tata Negara 
2. Suatu sistem keyakinan dan tata-ketentuan yang mengatur segala perikehidupan dan penghidupan asasi manusia dalam pelbagai hubungan: dengan Tuhan, sesama manusia, dan alam lainnya.

3. Bertujuan: keridhaan Allah, rahmat bagi segenap alam, kebahagiaan di dunia dan akhirat.

4. Pada garis besarnya terdiri atas akidah, syariatm dan akhlak.

5. Bersumberkan Kitab Suci Al-Quran yang merupakan kodifikasi wahyu Allah SWT sebagai penyempurna wahyu-wahyu sebelumnya yang ditafsirkan oleh Sunnah Rasulullah Saw.

Berdasarkan pemahaman Endang Saifuddin Anshari ini, dapat ditarik kesimpulan bahwa Islam adalah ajaran oleh Allah yang kepada Muhammad untuk disampaikan kepada segenap umat manusia yang di dalamnya mengandung ajaran terkait dengan segala aspek kehidupan baik menyakut akidah atau keyakinan, normanorma atau aturan-aturan hukum maupun yang berhubungan dengan sosial-budaya dalam artian bahwa ajaran-ajaran Islam mengandung sistem sosial-budaya yang dapat diterapkan dalam suatu masyarakat.

Dengan kata lain, Islam sebagai agama mengandung ajaran yang berkaitan dengan tata keyakinan atau belief dan aturan-aturan atau norm yang dapat dijadikan pijakan dalam kehidupan. Selain itu, Islam mengatur hubungan manusia dengan Tuhan, hubungan manusia dengan alam, maupun hubungan manusia dengan manusia dalam hubungan yang terakhir ini, dapat diterjemahkan bahwa ajaran Islam mengandung unsur yang dapat mengatur aspek kehidupan soial-budaya atau dapat dikatakan bahwa ajaran Islam mengandung sistem sosial-budaya yang dapat diterapkan dalam kehidupan umat manusia. Selain itu, Islam sebagai sebuah agama mengandung tata nilai etis yang dijadikan sebagai landasan pergaulan sosial masyarakat, seperti persamaan atau egalitarianisme, toleransi, akuntabilitas, keadilan, kebebasan, musyawarah, dan lain sebagainya. 
Sementara civil society diterjemahkan ke dalam bahasa Indonesia dengan sebutan masyarakat sipil atau masyarakat madani. Kata madani berasal dari kata Madinah, yaitu sebuah kota tempat hijrah Nabi Muhammad SAW. Madinah berasal dari kata "madaniyah" yang berarti peradaban. Oleh karena itu masyarakat madani berarti masyarakat yang beradaban. Masyarakat madani adalah sebuah tatanan masyarakat sipil civil society yang mandiri dan demokratis, masyarakat madani lahir dari proses penyemaian demokrasi. Tulisan ini selanjutnya membahas tentang masyarakat madani yang umumnya dikenal dengna istilah masyarakat sipil atau civil society pengertiannya, ciricirinya, sejarah pemikiran, karakter dan wacana masyarakat sipil di Barat dan di Indonesia serta unsur-unsur di dalamnya

Di bawah ini adalah beberapa definisi masyarakat madani sebagaimana yang penulis kutip dalam tulisan Muhammad Nashir sebagai berikut: ${ }^{7}$

1. Dalam kamus besar Bahasa Indonesia, masyarakat madani diartikan sebagai masyarakat yang menjunjung tinggi norma, nilai-nilai, dan hukum yang ditopang oleh penguasaan ilmu pengetahuan dan tehnologi serta iman.

2. Syamsudin Haris mendefinisikan masyarakat madani atau civil society adalah suatu lingkup interaksi sosial yang berada di luar pengaruh negara dan model yang tersusun dari lingkungan masyarakat paling akrab seperti keluarga, asosiasi sukarela, gerakan kemasyarakatan dan berbagai bentuk lingkungan komunikasi antar warga masyarakat.

3. Menurut Nurcholis Madjid, masyarakat madani atau civil society adalah masyarakat yang terinspirasi atau mengacu pada masyarakat Islam yang pernah dibangun Nabi Muhammad SAW di Madinah, sebagai masyarakat kota atau masyarakat berperadaban dengan ciri antara lain : egalitarian (kesederajatan), menghargai prestasi, keterbukaan, toleransi dan musyawarah.

4. Ernest Gellner, mendefinisikan Civil Society atau Masyarakat Madani mengacu pada mayarakat yang terdiri atas berbagai institusi non pemerintah yang otonom

\footnotetext{
${ }^{7}$ Muhammad Nashir "Pengertian Masyarakat Madani" dalam http://vexillumnsr.blogspot.co.id, diakses tanggal 25 Juli 2020
}

Qaumiyyah: Jurnal Hukum Tata Negara 
dan cukup kuat untuk dapat mengimbangi Negara.

5. Cohen dan Arato, mengartikan Civil society atau masyarakat madani adalah suatu wilayah interaksi sosial diantara wilayah ekonomi, politik dan Negara yang di dalamnya mencakup semua kelompok-kelompok sosial yang bekerjasama membangun ikatan-ikatan sosial diluar lembaga resmi, menggalang solidaritas kemanusiaan, dan mengejar kebaikan bersama (public good).

6. Sementara Muhammad AS Hikam mengartikan Civil Society atau Masyarakat Madani adalah wilayah-wilayah kehidupan sosial yang terorganisasi dan bercirikan antara lain kesukarelaan (voluntary), keswasembadaan (selfgenerating), keswadayaan (self-supporing), dan kemandirian yang tinggi berhadapan dengan negara, dan keterikatan dengan norma-norma dan nilai-nilai hukum yang diikuti oleh warganya.

Berdasarkan pengertian yang telah diuraikan sebelumnya dapat disimpulkan bahwa civil society atau masyarakat madani memiliki ciri sebagai berikut:

1. Masyarakat yang menjunjung tinggi nilai, norma dan hukum yang ditopang oleh penguasaan ilmu pengetahuan dan tehnologi serta Iman.

2. Masyarakat yang mempunyai peradaban yang tinggi.

3. Masyarakat yang memiliki pola interaksi sosial diluar pengaruh negara dan memiliki struktur sosial tersendiri yang dibangun berdasarkan asosiasi kekeluargaan dan sebagainya.

4. Masyarakat yang terdiri dari berbagai institusi atau organisasi sosial yang berdiri secara otonom dan menjadi kekuatan penyeimbang Negara.

5. Terbukanya ruang publik yang bebas sebagai wilayah dimana masyarakat memiliki akses terhadap kegiatan publik dan memiliki kebebasan untuk menyampaikan pendapat, berserikat dan sebagainya.

6. Menekankan sikap egalitarianisme, toleransi dan transparansi.

7. Penegakan supremasi agar teciptanya rasa keadilan bagi masyarakat.

b. Sinkretisasi Islam dengan Budaya Lokal dalam Konteks Indonesia 
Jika kita menelusuri potret ajaran Islam dalam konteks Indonesia kita akan mendapati berdasarkan perjalanan historisnya praktek ajaran Islam di Indonesia khususnya dalam konteks jawa yang berada di dalam lingkup wilayah kekuasaan kerajaan Majapahit dan Mataram menurut Harry J. Benda bukanlah Islam yang bersifat murni seperti halnya yang berasal dari Arab Saudi tetapi ia merupakan absorpsi-sinkretis berbagai aspek agama Islam kedalam kebudayaan Hindu-Jawa. Sehingga agama Islam terdomestikasi atau terjinakan dengan budaya Hindu-Jawa. ${ }^{8}$ Lebih jauh Benda menjelaskan bahwa di sebagian besar pulau Jawa, Islam dipaksa untuk menyesuaikan diri dengan tradisi-tradisi yang telah berabad-abad umurnya, sebagaian tradisi penduduk asli sebagian tradisi Hindu-Budha, dan dalam prosesnya banyak kehilangan kekakuan doktrinernya dan tidak menimbulkan perubahan yang radikal dalam kehidupan agama dan sosial di pulau Jawa. ${ }^{9}$

Sinkretisme Islam-Jawa sangat jelas terlihat dengan penggabungan antara agama dengan budaya lokal, yang dimaksud dalam konteks penggabungan agama dengan budaya lokal adalah melaksanakan syariat Islam dengan kemasan budaya Jawa. Dengan demikian, substansi syariat yang dijalankan tetap sesuai dengan koridor ajaran Islam, tetapi tampilan luarnya mengadopsi tradisi-tradisi lokal. Sebagai contoh, berbakti kepada orang tua dan bersaling memaafkan adalah sebuah kewajiban dalam Islam.Dalam melaksanakan syariat ini masyarakat Jawa biasanya menggunakan media sungkeman. Sungkem yang biasanya bertepatan dengan Hari Raya Idul Fitri tidak bisa terlewati tanpa hidangan kupat dan lontong. Dua hidangan tersebut merupakan simbol pengakuan manusia akan dosa dan saling memaafkan. Ajaran sinkretis ini di Jawa terutama dipraktekkan oleh kalangan priyayi dan abangan. $^{10}$

${ }^{8}$ Harry J. Benda, "Islam di Indonesia: Sepintas Lalu dalam Beberapa Segi" edd, Taufik Abdullah, (Jakarta: Tinta Mas, 1974) hlm. 43-44

${ }^{9}$ Harry J. Benda, "Bulan Sabit dan Matahari Terbit" penerjemah Daniel Dhakidae, (Jakarta: Pustaka Jaya, 1980) hlm. 30

${ }^{10}$ Musyafak, Saekul Anwar, dkk, "Sinkretisme Sebagai Bentuk dan Ciri Islam Jawa" dalam https://bangunaninteletual.wordpress.com, diakses tanggal 25 Juli 2020

Qaumiyyah: Jurnal Hukum Tata Negara 
Proses sinkretisme Islam dengan budaya lokal dapat juga kita lihat sebagaimana praktek Islam yang terjadi di Sasak, Lombok yang diteliti oleh Dr. Erni Budiwanti. Dia mengemukakan bahwa Islam Sasak adalah Islam juga, hanya saja Islam yang bernuansa lokal. Dalam agama wetu telu yang paling menonjol dan sentral adalah pengetahuan tentang lokal, tentang adat, bukan pengetahuan tentang Islam sama sekali, misalnya doa-doa, tempat peribadatan masjid dan tempat lain yang mengintroduksi keislaman mereka. ${ }^{11}$

Sinkretisme Islam dapat juga kita lihat dalam persingungannnnya dengan kebudayaan lokal seperti dalam masyarakat Bugis, bahwa ada sinergi antara keteguhan dalam adat dengan ketaatan beragama. Dengan menjadikan adeq (adat) dan saraq (syariat) keduanya sebagai struktur dalam panggaderreng (undang-undang sosial), maka ini menyatukan fungsi keduanya dalam mengatur kehidupan. Selanjutnya dalam banyak aktivitas adat telah diadaptasi dengan prinsip-prinsip keislaman. Islam diterjemahkan ke dalam perangkat kehidupan lokal dengan tetap mempertahankan pola yang ada kemudian ditransformasi ke dalam esensi tauhid. Dengan menggunakan potensi lokal ini digunakan sebagai strategi untuk membangun spiritualitas tanpa karakter kearaban. Islam dalam nuansa adat Bugis diinterpretasi kedalam nilai dan tradisi sehingga membentuk identitas masyarakat Bugis. Akhirnya, perjumpaan adat dan agama dalam budaya masyarakat Bugis menunjukkan telah terjadi dialog dan merekonstruksi sebuah budaya baru dalam nuansa lokal. ${ }^{12}$

Dari pemaparan terkait sinkretisasi Islam dengan budaya lokal dapat dikatakan bahwa Islam sebagai sebuah ajaran yang bersifat universal dalam prakteknya ketika berhadapan dengan budaya dalam konteks ke Indonesiaan selalu menyesuaikan dan terjadi proses akulturasi dan sinkretisasi dengan budaya lokal. Penerimaan masyarakat terhadap Islam dalam kontek Indonesia bukanlah sesuatu yang tanpa syarat dan menerima secara bulat ajaran Islam sebagaimana yang di impor

$\begin{array}{ccccc}{ }^{11} \text { Fathoni, "Sinkretisme Islam Nusantara: } & \text { Terbentuk atau } & \text { Dibentuk?" } & \text { dalam } \\ \text { http://www.nu.or.id, diakses tanggal 25 Juli } 2020 & & & \\ { }^{12} \text { Kasman } \quad \text { Renyaan, "Akulturasi } & \text { Kebudayaan } & \text { Islam" } & \text { dalam } \\ \text { http://amaholugeneration.blogspot.co.id, diakses tanggal 25 Juli } 2020 & \end{array}$

Qaumiyyah: Jurnal Hukum Tata Negara 
dari Timur tengah secara umum maupun Arab Saudi secara khusus tanpa proses penyaringan dengan budaya setempat akan tetapi adanya proses perkawinan dan sinkretisasi dengan budaya lokal. Sehingga kondisi Islam yang menyatu dengan budaya lokal seperti ini, menyiapakan suatu lahan yang dapat membangun dan memperkuat sendi-sendi kehidupan masyarakat sesuai dengan kearifan lokal.

\section{c. Peran Islam dalam Penguatan Civil Society di Indonesia}

Menjelaskan tentang peran Islam dalam penguatan civil society atau masyarakat madani di Indonesia penulis membacanya dan menganalisisnya dalam dua hal yang pertama melalui ajaran Islam. Kedua, melalui proses sinkretisasi Islam dengan budaya lokal.

Pertama, Islam sebagai agama didalamnya terdapat ajaran yang berkaitan dengan keyakinan, norma atau aturan-aturan maupun yang berhubungan dengan sosial-budaya serta terkandung ajaran-ajaran etis yang dapat mengatur kehidupan sosial masyarakat. Menurut penulis dalam ajaran Islam tersebut mengandung penguatan terhadap civil society. ini dapat kita jelaskan secara lebih jauh bahwa beberapa ciri dari civil society sebagaimana yang telah diuraikan sebelumnya seperti menjunjung tinggi nilai-nilai, norma dan hukum, memiliki sebuah institusi sosial yang bersifat otonom sebagai alat pengontrol kekuasaan atau Negara, terciptanya ruang publik yang bebas bagi masyarakat, menekankankan sikap egalitarianisme atau persamaan, toleransi serta menegakkan supremasi hukum. Seperti kita ketahui bahwa Islam adalah sebuah ajaran yang di dalamnya terdapat norma atau aturan-aturan serta hukum dan Islam mendorong terciptanya keadilan dalam suatu masyarakat. Hal ini, jika ditafsirkan bahwa Islam sangat menjunjung tinggi norma dan aturan-aturan serta mendorong penegakkan supremasi hukum yang menciptakan suatu keadilan bagi masyarakat. Selain itu, Islam melalui ajarannya sangat menekankan terhadap persamaan dalam masyarakat terwujudnya toleransi serta kebebasan berekspresi bagi

masyarakat. Dan juga, Islam sebagai agama memberikan kekuatan pembebas dari segala sikap tirani dan budaya yang membelunggu masyarakat dan mampu menjadi alat 
pengontrol kekuasaan guna mendorong penguatan terhadap civil society yang tercermin dalam ajaran keyakina atau tauhid kepada Tuhan.

Kedua, dalam melihat peran Islam dalam penguatan civil society di Indonesia membacanya dari konteks sinkretisasi budaya Islam dengan budaya lokal. Sebagaimana kita ketahui dari penjelasan sebelumnya bahwa ajaran Islam dalam konteks Indonesia mengalami proses sinkretisasi atau perpaduan dengan budaya lokal. Proses sinkretisasi ini mempunyai implikasi terhadap pengembangan nilai-nilai dan norma kearifan lokal dan menghilangkan aspek negatif yang tidak konstruktif dari budaya lokal. Islam sebagai sebuah agama memasukkan ajaran-ajaran yang bersifat etis dan positif kedalam unsur budaya lokal yang dapat menjadi inspirasi untuk pengembangan masyarakat maupun organisasi-organisasi yang berbasis lokal teruatama organisasi-organisasi berdasarkan pada adat, sehingga dapat dikatakan melalui analisis sinkretiasasi Islam ini secara tidak langsung Islam mendorong terhadap penguatan budaya lokal.

\section{Kesimpulan}

Mengacu pada pembahasan sebelumnya, dapat disimpulkan beberapa hal terkait tema "Islam dan Penguatan Civil " sebagai berikut:

Islam sebagai sebuah ajaran yang bersifat universal dalam prakteknya ketika berhadapan dengan budaya dalam konteks ke Indonesiaan selalu menyesuaikan dan terjadi proses akulturasi dan sinkretisasi dengan budaya lokal. Penerimaan masyarakat terhadap Islam dalam kontek Indonesia bukanlah sesuatu yang tanpa syarat dan menerima secara bulat ajaran Islam sebagaimana yang di impor dari Timur tengah secara umum maupun Arab Saudi secara khusus tanpa proses penyaringan dengan budaya setempat akan tetapi adanya proses perkawinan dan sinkretisasi dengan budaya lokal.

Islam dalam penguatan civil society di Indonesia membacanya dari konteks sinkretisasi budaya Islam dengan budaya lokal. Proses sinkretisasi ini mempunyai implikasi terhadap pengembangan nilai-nilai dan norma kearifan lokal dan menghilangkan aspek negatif yang tidak konstruktif dari budaya lokal. Islam sebagai Qaumiyyah: Jurnal Hukum Tata Negara 
sebuah agama memasukkan ajaran-ajaran yang bersifat etis dan positif kedalam unsur budaya lokal yang dapat menjadi inspirasi untuk pengembangan masyarakat maupun organisasi-organisasi yang berbasis lokal teruatama organisasi-organisasi berdasarkan pada adat, sehingga dapat dikatakan melalui analisis sinkretiasasi Islam ini secara tidak langsung Islam mendorong terhadap penguatan budaya lokal.

\section{DAFTAR PUSTAKA}

Anshari, Endang Saifuddin, Kuliah Al-Islam, Bandung: Pustaka 1978

A. Ubaidillah...(et.al), "Pendidikan Kewargaan Demokrasi, HAM dan Masyarakat Madani” (cet.1) Jakarta: IAIN Jakarta Press, 2000

Benda, Harry J., “Islam di Indonesia: Sepintas Lalu dalam Beberapa Segi” edd, Taufik Abdullah, Jakarta: Tinta Mas, 1974

Benda, Harry J., "Bulan Sabit dan Matahari Terbit” penerjemah Daniel Dhakidae, Jakarta: Pustaka Jaya, 1980

Culla, Adi Suryadi, "Rekonstruksi Civil Society: Wacana dan Aksi Ornop di Indonesia” Jakarta: Pustaka LP3ES Indonesia, 2006

Fathoni, "Sinkretisme Islam Nusantara: Terbentuk atau Dibentuk?" dalam http://www.nu.or.id, diakses tanggal 25 Juli 2020

Musyafak, Saekul Anwar, dkk, "Sinkretisme Sebagai Bentuk dan Ciri Islam Jawa" dalam https://bangunaninteletual.wordpress.com, diakses tanggal 25 Juli 2020

Nashir, Muhammad, "Pengertian Masyarakat Madani” dalam http://vexillumnsr.blogspot.co.id, diakses tanggal 25 Juli 2020

Prasetyo, Hendro ...(et.al), "Islam dan Civil Society: Pandangan Muslim Indonesia" Jakarta: PT Gramedia Pustaka Utama, 2002

Renyaan, Kasman, "Akulturasi Kebudayaan Islam" dalam http://amaholugeneration.blogspot.co.id, diakses tanggal 25 Juli 2020

Sufyanto, Masyarakat Tamaddun Kritik Hermeneutis Masyarakat Madani Nurcholish Madjid, Yogyakarta: Pustaka Pelajar dan LP2IF, 2001 